\title{
A Multi-Dimensional View Of Socio-Technical Information Systems Research And Technochange
}

Angela Mattia, Jacksonville University, USA

\begin{abstract}
Technical change is almost always the catalyst for organization change. Technochange is the use of information technology to drive improvements in organizational performance. Therefore, the objective of this paper is to continue the movement from socio-technical thinking to technochange thinking by analyzing the socio-technical research on information technology projects from different viewpoints. This is accomplished by using a multi-dimensional framework that delivers a fresh research perspective into the information technology, human and organization aspects of technochange. The results are a socio-technochange conceptual frame for the types of statistical analysis employed, the level of analysis conducted, the logical relationships between the causes and the outcomes, and the impact on the organization. This provides a coherent synopsis of the tools and interpretations needed to give us sufficient background to better understand technochange and its relationship to improved organizational performance.
\end{abstract}

Keywords: Information Systems Development; Socio-Technical; Project Management; Change Management; Organizational Change; Multi-Dimensional Analysis; Technochange

\section{INTRODUCTION}

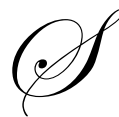

ocio-technical theory, socio-technical design, and socio-technical approaches began emerging in the middle of the $20^{\text {th }}$ century, as an alternative to the mainstream technical approach to information systems development. The basic premise of the socio-technical viewpoint suggested that what was needed was a fit within an organization, between the technical and social subsystems. The socio-technical approach suggests that a fit is achieved by a design process aiming at the joint optimization of the subsystems. The interdependence of the subsystems must be recognized for maximized performance to be achieved. In addition, the subsystems must work in harmony to ensure superior results. Consequently, humanistic principles, behavioral problems, managerial values and the systems designers' frames of reference (Bostrom \& Heinen 1977) are reflected in socio-technical thinking.

Today, in this socio-technical world, understanding an information system will need to include an understanding of the human and organizational aspects that embed and situate how people interact with and through the information systems at hand in the course of their work and workflows (Scacchi 2003). Hence, the most important thing that socio-technical design can contribute is its value system, which tells us that although technology and organizational structures may change, a balance (Doherty, et al. 2006) of all parts (human and non-human) must be maintained. (Mumford 2006) extends the discussion to future scenarios where he speculates that socio-technical principles might emerge. One scenario is that technology in the workplace will be humanized in a world where consistent organizational and economic changes are the norm.

The objective of this paper is to continue the movement from technical and socio-technical thinking to technochange thinking by delivering a coherent collection of information systems research that can provide significant new insights into technochange management. This research provides a variety of different perspectives and viewpoints as they try to illuminate different aspects of this complex dilemma. A multi-dimension view shows a variety of conceptual lens, such as statistical analysis that are employed and level of analysis are conducted, the 
logical relationships between the causes and the outcomes, and the impact on the organization. The result is a coherent synopsis of the tools and interpretations of prior research and the relationship to technochange management. In addition, it gives us sufficient background to better understand and use IT to drive improvements in organizational performance.

Technical change is almost always the catalyst for organization change (Doherty \& King 2005). If this argument is true, then in a world where consistent organizational and economic changes are the norm, will these changes be a catalyst for technical change? One recent study on technochange management improvements in organizational performance (Markus 2004) is an approach where IT is strategically used to drive organizational (change) performance improvements. Effective technochange management requires a different kind of attention to the features of the 'solution' and a different change process from those prescribed by either IT project management or organizational change management (Figure 1). Therefore, it is fundamentally different from both IT projects and organizational change programs. Successful technochange is characterized by completeness; it is a fit between the technochange solution and organizational processes, culture, and incentives. Successful technochange involves careful up front design, a balancing act of the technical and social subsystems and integrated technical and organizational implementation.

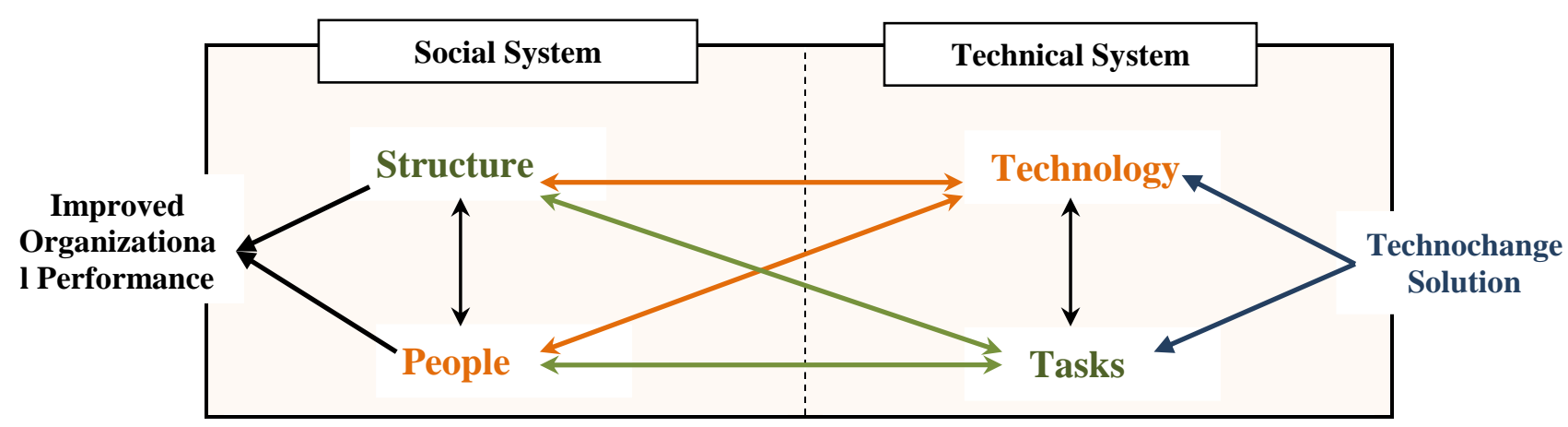

Figure 1. Technochange Solution Uses IT to Drive Improved Organizational Performance Adapted from (Markus 2004; Bostrom \& Heinen 1977)

\section{METHOD}

It is possible for this research to offer many plausible theories, approaches and explanations as to what works and doesn't work in information systems projects, but this paper will use numerous socio-technical research dimensions to evaluate a selection of current papers. The multi-dimensional analysis will include the 3 dimensions put forth in the Markus and Robey (1988) paper and a few others deemed by this researcher to be important that will also be described. Causal agency (i.e., causal agent and its influence), is the first dimension. This dimension refers to the analyst's assumptions and the identity of the agent and the direction of the causal influence (Table 1).

Table 1. Causal Agency Derived from (Markus \& Robey 1988)

\begin{tabular}{|ll|l|}
\hline \multicolumn{2}{|c|}{ Causal Agent } & \multicolumn{1}{c|}{ Direction of the causal influence } \\
\hline Technology & (Technological imperative) & External forces cause change \\
\hline Organizational & (Organizational imperative) & People act purposefully to accomplish intended objectives \\
\hline Emergent & (Emergent imperative) & Change emerges from the interaction of people and events. \\
\hline
\end{tabular}

Markus and Robey (1988) conducted a study that examined the causal structures found in theories and research about the relationship between information technology and organizational change. They focused on the 3 dimensions of causal structure: 1. causal agency, 2. logical structure, and 3. level of analysis. This study concluded that very few good theories about the role of information technology in organizational change exist, although there 
is the potential for more. Is this conclusion still valid? The socio-technical model was expanded in 2008 to include both incremental and punctuated socio-technical change in the context of information systems at multiple levels the work system level, the building system level, and the organizational. (Lyytinen \& Newman 2008).

Therefore, the second dimension is logical structure, which refers to the logical relationships between the causes and the outcomes. This refers to the time span of the theory (variance models versus process models). Third is the level of analysis, which refers to the entities (collectives $=$ macro, individual $=$ micro, or both $=$ mixed) about which the theory poses concepts and relationships.

A group of studies ranging from 2005 to 2010 were selected that were representative of the larger set of research allowing us an exploratory look at socio-technical thinking and the relationship to technochange. Although there are many articles discussing the human and organizational aspects of system development, only relatively few are rigorously conducted case studies or report on actual statistical analysis results that address the requirements of this study.

For my review, the articles were selected that meet the following requirements:

- a clear specification of the type of data;

- $\quad$ the research method is specified;

- $\quad$ Causal agency can be determined;

- $\quad$ Logical structure can be determined;

- $\quad$ Level of analysis can be determined;

- Well-presented results that show the organizational impact of IT projects.

\section{RESULTS}

A socio-technochange framework (Table 2) allows for a treatise of studies to be analyzed from a multidimensional viewpoint. The articles are briefly summarized to make additional contextual information available. Table 2 and the summarized articles show a spectrum of recently published viewpoints, and illuminate the six dimensions of prior socio-technical research. Some of the results are as would be expected, but others provide insight into the fit between the technical and social subsystems.

- $\quad$ Case studies were the dominant method of research, with qualitative data being collected and analyzed.

- Causal agency had mixed instances, but interestingly enough, emergent imperative was 50\% of the direction of the causal influence. This would suggest that effective business solutions would need to manage the change that results from the interaction of people and events.

- The logical structure was predominantly process models as would be expected, when doing case studies, which focus on dynamic outcomes, but what is worth noting, is the broad range of theories used as the conceptual lens for understanding the studies.

- The level of analysis (micro, macro, and mixed) had mixed instances, which would suggest that case studies are flexible in the level of analysis needed. Therefore, it can be decided on a case-by-case basis.

- The organizational impact supported the observation that emerging in the literature is the realization that results are contextualized.

The movement from socio-technical to technochange (Markus 2004) thinking:

- Successful technochange is characterized by completeness; it is a fit between the technical subsystem, social subsystem, technochange solution and the improved organizational performance.

- Successful technochange management involves careful up front design that includes managing the change that results from the interaction of people, structure, tasks and information technology.

- A balancing act of the technical and social subsystems is part of the process model for dynamic technochange outcomes. 
- Integrated technical and organizational implementation can be decided on a case-by-case basis, but the technochange outcome must be to improve organizational performance.

- Organizational impact is contextualized, therefore technochange solutions can vary and adapt from situation to situation.

Table 2: Multi-Dimensional Analysis of Socio-Technical Research and Technochange

\begin{tabular}{|c|c|c|c|c|c|c|}
\hline $\begin{array}{c}\text { Authors/ } \\
\text { Date of Study }\end{array}$ & $\begin{array}{l}\text { Type of } \\
\text { Data }\end{array}$ & $\begin{array}{l}\text { Research } \\
\text { Method }\end{array}$ & Causal Agency & $\begin{array}{c}\text { Logical } \\
\text { Structure }\end{array}$ & $\begin{array}{c}\text { Level of } \\
\text { Analysis }\end{array}$ & Organizational Impact \\
\hline $\begin{array}{l}\text { (Davidson \& } \\
\text { Chiasson } \\
\text { 2005) }\end{array}$ & Qualitative & $\begin{array}{l}\text { Comparative } \\
\text { Case Study }\end{array}$ & Organizational & $\begin{array}{l}\text { Process } \\
\text { Theories/ } \\
\text { TUM concepts } \\
\text { as an analytic } \\
\text { lens. }\end{array}$ & Mixed & $\begin{array}{l}\text { Mediation was vitally important } \\
\text { with these specialized IT } \\
\text { artifacts, and that system } \\
\text { configuration required changes } \\
\text { to software infrastructure and } \\
\text { code. }\end{array}$ \\
\hline $\begin{array}{l}\text { (Luna-Reyes, } \\
\text { et al. 2005) }\end{array}$ & Qualitative & $\begin{array}{l}\text { Longitudinal } \\
\text { Case Study }\end{array}$ & Emergent & $\begin{array}{l}\text { Process } \\
\text { Theories/ Socio- } \\
\text { technical } \\
\text { approaches }\end{array}$ & Mixed & $\begin{array}{l}\text { Change in professional practice } \\
\text { are characterized as an iterative } \\
\text { process of sense making among } \\
\text { stakeholders }\end{array}$ \\
\hline $\begin{array}{l}\text { (Kotlarsky \& } \\
\text { Oshri 2005) }\end{array}$ & Qualitative & $\begin{array}{l}\text { Ethnographic } \\
\text { Case Study }\end{array}$ & Emergent & $\begin{array}{l}\text { Process } \\
\text { Theories/ Social } \\
\text { construction }\end{array}$ & Micro & $\begin{array}{l}\text { Social practice is the primary } \\
\text { activity for change and } \\
\text { collaboration is one of its } \\
\text { characteristics. }\end{array}$ \\
\hline $\begin{array}{l}\text { (Lee \& Xia } \\
2005)\end{array}$ & Quantitative & $\begin{array}{l}\text { Survey } \\
\text { Research }\end{array}$ & Organizational & $\begin{array}{l}\text { Variance } \\
\text { Theories/ Socio- } \\
\text { technical } \\
\text { approaches }\end{array}$ & Macro & $\begin{array}{l}\text { List of changes included } 24 \\
\text { types of business changes and } \\
10 \text { types of technology changes. }\end{array}$ \\
\hline $\begin{array}{l}\text { (Lin \& Silva } \\
2005)\end{array}$ & Qualitative & Case Study & Emergent & $\begin{array}{l}\text { Process } \\
\text { Theories/ } \\
\text { Technological } \\
\text { frames analysis } \\
\text { as a theoretical } \\
\text { lens. }\end{array}$ & Micro & $\begin{array}{l}\text { Social phenomena such as } \\
\text { language, symbolic power, and } \\
\text { communication processes are } \\
\text { fundamental for understanding } \\
\text { how technological } \\
\text { interpretations are framed. }\end{array}$ \\
\hline $\begin{array}{l}\text { (Chae \& Poole } \\
\text { 2005) }\end{array}$ & Qualitative & Case Study & Technological & $\begin{array}{l}\text { Process } \\
\text { Theories/ } \\
\text { Structuration \& } \\
\text { actor-network } \\
\text { theory }\end{array}$ & Mixed & $\begin{array}{l}\text { Pre-existing IS may } \\
\text { emerge as more active and } \\
\text { influential in enterprise } \\
\text { system development than in } \\
\text { traditional, small-scale IS. }\end{array}$ \\
\hline $\begin{array}{l}\text { (Hatzakis, et } \\
\text { al. 2005) }\end{array}$ & $\begin{array}{l}\text { Qualitative } \\
\& \\
\text { Quantitative }\end{array}$ & $\begin{array}{l}\text { Case study \& } \\
\text { Survey } \\
\text { Research }\end{array}$ & Emergent & $\begin{array}{l}\text { Process } \\
\text { Theories/ } \\
\text { Social capital } \\
\text { theory }\end{array}$ & Macro & $\begin{array}{l}\text { Conceptualization } r \text { and } \\
\text { operationalization of social } \\
\text { capital theory to explain the role } \\
\text { of change management } \\
\text { initiatives. }\end{array}$ \\
\hline $\begin{array}{l}\text { (Doherty, et al. } \\
\text { 2006) }\end{array}$ & Qualitative & Case Study & Technological & $\begin{array}{l}\text { Process } \\
\text { Theories/ } \\
\text { Interpretive } \\
\text { flexibility }\end{array}$ & Macro & $\begin{array}{l}\text { Human agents shape the } \\
\text { technical artifact, and the } \\
\text { artifact's shaping potential to } \\
\text { humans. }\end{array}$ \\
\hline $\begin{array}{l}\text { (LeRouge, et } \\
\text { al. 2007) }\end{array}$ & Quantitative & $\begin{array}{l}\text { Field Study/ } \\
\text { Survey }\end{array}$ & Organizational & $\begin{array}{l}\text { Socio-technical } \\
\text { perspective/ }\end{array}$ & Micro & $\begin{array}{l}\text { A socio-technical framework for } \\
\text { use quality in telemedicine. }\end{array}$ \\
\hline $\begin{array}{l}\text { (Choi, et al. } \\
\text { 2008) }\end{array}$ & Quantitative & Field Study & Organizational & $\begin{array}{l}\text { Socio-technical } \\
\text { perspective }\end{array}$ & Micro & $\begin{array}{l}\text { Social enablers are more } \\
\text { important than technical support } \\
\text { in facilitating knowledge sharing }\end{array}$ \\
\hline $\begin{array}{l}\text { (Mackrell, et } \\
\text { al. 2009) }\end{array}$ & Qualitative & $\begin{array}{l}\text { Interpretative } \\
\text { Case Study }\end{array}$ & Emergent & $\begin{array}{l}\text { Innovation- } \\
\text { decision model/ } \\
\text { socio-technical } \\
\text { approach. }\end{array}$ & Micro & $\begin{array}{l}\text { Found that implementation } \\
\text { success came from reflexive and } \\
\text { resourceful adaptation of } \\
\text { technology to meet changing } \\
\text { and unanticipated needs. }\end{array}$ \\
\hline $\begin{array}{l}\text { (Bygstad, et al. } \\
\text { 2010) }\end{array}$ & Qualitative & $\begin{array}{l}\text { Longitudinal } \\
\text { Case Study }\end{array}$ & Emergent & $\begin{array}{l}\text { Software } \\
\text { engineering/ } \\
\text { Socio-technical } \\
\text { approaches }\end{array}$ & Mixed & $\begin{array}{l}\text { Management challenges have } \\
\text { patterns that are context- } \\
\text { sensitive. }\end{array}$ \\
\hline
\end{tabular}


Below is a brief description of each of the selected studies.

Contextual influences on technology use mediation: a comparative analysis of electronic medical record systems. (Davidson \& Chiasson 2005)

Davidson \& Chiasson uses two separate healthcare organizations that operate electronic medical record systems to explore and provide insight into technology use mediation (TUM) process (Orlikowski W. J., et al. 1995). In addition, TUM is used as a conceptual lens, to examine how software technologies and social practices are mutually shaped during information technology projects. The authors concluded that crucial TUM actions occurred during systems development phases as well as during system use, that mediation was vitally important with these specialized IT artifacts, and that system configuration required changes to software infrastructure and code. Organizational size influenced the availability and the effectiveness of mediation resources; with adequate resources committed to the task, the institutional environment presented substantial, but not insurmountable, challenges to technology use mediation

Information systems development as emergent socio-technical change: a practice approach (Luna-Reyes, et al. 2005)

This paper explores the dynamics of these social and organizational factors to better understand the causes of success and failure through a longitudinal study in a NY State agency. Based on data from a detailed case analysis of an ISD project, the paper depicts the ISD process as an emergent and dynamic process-oriented view of information systems, characterized by continuous local adaptations. The paper ends with a proposal of a feedbackrich framework, which offers a theoretical explanation of the information systems development process based on a practice view of socio-technical change.

Social ties, knowledge sharing and successful collaboration in globally distributed system development projects (Kotlarsky \& Oshri 2005)

This paper studies successful collaboration in globally distributed IS development teams due to the contribution of social ties and knowledge sharing. Data (codified using Atlas.ti software) were drawn from two successful globally distributed system development project teams at SAP and LeCroy. The results suggest that human and organizational aspects, such as rapport and transactive memory, were important for collaborative work in the teams studied within the systems development context.

The ability of information systems development project teams to respond to business and technology changes: a study of flexibility measures (Lee \& Xia 2005)

The ISDP team's flexibility in responding to organizational and technical changes has become a critical success factor for system development, but the research literature lacks a consistent definition and validated measures of the construct. Drawing upon the socio-technical and the capability-based perspectives and using a systematic multi-stage approach, the authors identified major business and technology changes and developed measurement scales of ISDP team flexibility along two dimensions: Response Extensiveness and Response Efficiency. The results of the study indicated that while the ISDP teams experienced and responded more extensively to business changes than technology changes, they were much less efficient in dealing with business changes than technology changes.

The social and political construction of technological frames (Lin \& Silva 2005)

The authors of this paper explore the dynamic nature of technology frames, in information systems development. In particular, this work argues that the management of information systems' adoption is a social and political process in which stakeholders frame and reframe due to the changing context, their perceptions of an information system. A case study carried out in a European bank illustrates how the Bank's technical team influenced users' technological frames, including those of senior management in order to ensure a smooth implementation process. 
The surface of emergence in systems development: agency, institutions, and large-scale information systems (Chae \& Poole 2005)

The systems development literature has primarily focused on the system under development, and the role of pre-existing information systems is treated as constraint on development or completely ignored. A case study is used to explore the role of pre-existing information systems in the development of a new system within a major university system in the U.S. The case study develops the argument that pre-existing information systems are active forces in systems development because of the experiences and learning from previous systems, which shape developers' approaches to building the new system. The study also develops a theoretical framework that integrates elements of structuration theory and actor-network theory to provide a more fine-grained analysis of how information technologies and institutional features interact in the structuring of organizational information systems.

Towards the development of a social capital approach to evaluating change management interventions. (Hatzakis, et al. 2005)

The poor relationship, collaboration and communication between business and IT colleagues before, during and after information systems development lead to dissatisfaction with information systems and services. To address these relational issues, relationship management initiatives (RM) have been introduced and in response, this paper proposes a framework, based on social capital theory, for conceptualizing the effects of change management interventions. It uses a case study and questionnaire to explore the strengths and limitations of the approach, and concludes that there is potential merit in using a social capital approach for the evaluation of change management interventions.

A re-conceptualization of the interpretive flexibility of information technologies: redressing the balance between the social and the technical. (Doherty, et al. 2006)

Interpretive flexibility is the capacity of a specific technology to sustain divergent opinions due to its social construction, but a gap exists in the literature on how a system's technical characteristics might limit its ability to be interpreted flexibly. In this paper, the authors use the results of two in-depth case studies, in order to propose a reconceptualization of the role of interpretive flexibility by looking at the role of the human agent in shaping the technical artifact, and the artifact's shaping potential. In summary, this model helps explain how the initial interpretations of stakeholders are influenced by the scope and adaptability of the system's functionality, while the stakeholder interpretations will then, in turn, influence how the system's functionality is appropriated and exploited by users.

It's more than just use: An exploration of telemedicine use quality. (LeRouge, et al. 2007)

This research specifies the use quality construct in the context of medical video conferencing for patient exams. The product of this field study is a socio-technical framework for use quality in telemedicine. Generalized categories (which may extend across domains) for identifying attributes, providing a comparative overview of patient and provider perspectives and discussing the effects of and remedies for selected attribute deficiencies are provided.

The effects of socio-technical enablers on knowledge sharing: an exploratory examination. (Choi, et al. 2008)

The study provides a better understanding of how these enablers can affect knowledge sharing intention and behavior, and explore practical implications for knowledge sharing. It proposes a theoretical model to investigate these enablers from a socio-technical perspective. PLS (Partial Least Square) analysis was employed to validate the model. This field study involves 164 user and reveals that social enablers such as trust and reward mechanisms are more important than technical support in isolation for facilitating knowledge sharing.

A qualitative case study of the adoption and use of an agricultural decision support system in the Australian cotton industry: The socio-technical view. (Mackrell, et al. 2009) 
This study is an interpretive case study which explores the adoption and use of an agricultural decision support system. The study uses an innovation-decision model and he technology-in-practice model that uses a sociotechnical approach. The results suggested that implementation success stemmed from being reflexive and resourceful in adapting the technology to unanticipated and changing needs.

Four integration patterns: a socio-technical approach to integration in IS development Projects. (Bygstad, et al. 2010)

This study draws on socio-technical IS research and software engineering research. Four generic patterns of integration: big bang, stakeholder integration, technical integration and socio-technical integration are patterns presented. Each pattern has advantages and disadvantages. Three longitudinal case studies were conducted which investigate the management challenges for each pattern. The study found that the patterns are context-sensitive and describe the different contexts where the patterns are applicable.

\section{CONCLUSION}

In summary, information technology projects often are treated as technical change processes, rather than technology driven social or organizational change processes. While the development of technical systems is an important component of systems development, the achievement of technology adding business value is the principal organizational goal. With this in mind, a coherent review of prior research is provided that includes a discourse on how the human and organizational aspects of systems development projects can be successfully managed to result in effective technochange solutions. This treatise was summarized in Table 2. It showed a spectrum of recently published viewpoints, and illuminated six dimensions of socio-technical research in information technology project management.

The information systems literature reviewed is clear on three points: a good "fit" and a balance of technical and organization aspects are needed; the primary need is to adequately predict and manage organizational impacts; emerging in the literature is the realization that the result of organizational change is contextualized. Consequentially, this paper continues the movement from socio-technical to technochange thinking by delivering significant new insights into technochange and exploring how it relates socio-technical thinking. This research confirms that successful technochange involves careful up front design, a balancing act of the technical and social subsystems and integrated technical and organizational implementation (Markus 2004). This research extends the definition by adding to it that successful technochange has an organizational impact that is contextualized. Therefore, technochange solutions can vary and adapt from situation to situation.

Future work would need to expand the range of the papers to more articles in other journal. The inclusion of additional research papers could provide a broader range of conceptual lens (theories) that are used, statistical analysis employed, and level of analysis conducted. They could provide new tools and new interpretations, new concepts or approaches for analyzing the organizational impacts of information technology projects. This research engages those of us concerned with information technology project management to proactively develop better ways of conducting technochange.

\section{AUTHOR INFORMATION}

Angela Mattia is an assistant professor of Decision Sciences and Information Management in the Davis College of Business at Jacksonville University located in Jacksonville Florida. Her research interests include data management, information systems innovation and project management. Mattia received a Ph.D. in information systems from Virginia Commonwealth University. Her contact address is: Jacksonville University, 2800 University Blvd N, Jacksonville, FL 32211, E-mail: amattia@ju.edu

\section{REFERENCES}

1. Bygstad, B., Nielsen, P. A., \& Munkvold, B. E. (2010). Four integration patterns: a socio-technical approach to integration in IS development projects. Information Systems Journal, 20(1), 53-80. 
2. Chae, B., \& Poole, M. S. (2005). The surface of emergence in systems development: agency, institutions, and large-scale information systems. European Journal of Information Systems, 14(1), 19.

3. Choi, S. Y., Kang, Y. S., \& Lee, H. (2008). The effects of socio-technical enablers on knowledge sharing: an exploratory examination. Journal of Information Science, 34(5), 742.

4. Davidson, E., \& Chiasson, M. (2005). Contextual influences on technology use mediation: a comparative analysis of electronic medical record systems. European Journal of Information Systems, 14(1), 6.

5. Doherty, N. F., Coombs, C. R., \& Loan-Clarke, J. (2006). A re-conceptualization of the interpretive flexibility of information technologies: redressing the balance between the social and the technical.

European Journal of Information Systems, 15(6), 569.

6. Doherty, N. F., \& King, M. (2005). From technical to socio-technical change: tackling the human and organizational aspects of systems development projects. European Journal of Information Systems 14(1), 1.

7. Hatzakis, T., Lycett, M., Macredie, R. D., \& Martin, V. A. (2005). Towards the development of a social capital approach to evaluating change management interventions. European Journal of Information Systems, 14(1), 60.

8. Kotlarsky, J., \& Oshri, I. (2005). Social ties, knowledge sharing and successful collaboration in globally distributed system development projects. European Journal of Information Systems, 14(1), 37.

9. Lee, G., \& Xia, W. (2005). The ability of information systems development project teams to respond to business and technology changes: a study of flexibility measures. European Journal of Information Systems, 14(1), 75.

10. LeRouge, C., Hevner, A. R., \& Collins, R. W. (2007). It's more than just use: An exploration of telemedicine use quality. Decision Support Systems, 43(4), 1287-1304.

11. Lin, A., \& Silva, L. (2005). The social and political construction of technological frames. European Journal of Information Systems, 14(1), 49.

12. Luna-Reyes, L. F., Zhang, J., Gil-García, J. R., \& Cresswell, A. M. (2005). Information systems development as emergent socio-technical change: a practice approach. European Journal of Information Systems, 14(1), 93.

13. Lyytinen, K., \& Newman, M. (2008). Explaining information systems change: a punctuated socio-technical change model. European Journal of Information Systems, 17(6), 589-613.

14. Mackrell, D., Kerr, D., \& von Hellens, L. (2009). A qualitative case study of the adoption and use of an agricultural decision support system in the Australian cotton industry: The socio-technical view. Decision Support Systems, 47(2), 143-153.

15. Markus, M. L. (2004). Technochange management: using IT to drive organizational change. Journal of Information Technology, 19(1), 4.

16. Markus, M. L., \& Robey, D. (1988). Information Technology and Organizational Change: Casual St. Management Science, 34(5), 583.

17. Mumford, E. (2006). The story of socio-technical design: reflections on its successes, failures and potential. Information Systems Journal, 16(4), 317-342.

18. Orlikowski W. J., Yates J., Okamura K., \& M., F. (1995). Shaping electronic communication: the metastructuring of technology in the context of use. Organization Science, 6(4), 423-444.

19. Robert P. Bostrom, \& Heinen, J. S. (1977). MIS Problems and Failures: A Socio-Technical Perspective. MIS Quarterly, 1(3), pp. 17-32.

20. Scacchi, W. (Ed.) (2003) The Encyclopedia of Human-Computer Interaction Berkshire Publishing Group, 2004. 